\title{
DETERMINASI EFISIENSI MODAL KERJA DAN LIKUIDITAS TERHADAP PROFITABILITAS PADA PERUSAHAAN SEKTOR FARMASI YANG TERDAFTAR DI BEI
}

\author{
Rina Dameria Napitupulu \\ Jurusan Akuntansi, STIE JAYAKARTA, Indonesia. \\ Rinanapitupulu_dew@yahoo.com
}

\begin{abstract}
This research aims to analyze the determination of working capital efficiency and liquidity towards profitability in the pharmaceutical companies listed on the Indonesia stock exchange. Research using quantitative research approach with the method of korelasional regression. The data of the secondary data is taken from BEI. Results of the study showed: first working capital (working capital turnover) affect to profitability (return on assets), second receivable turnover affect to profitability (return on assets), third inventory turnover affect to profitability (return on assets), fourth liquidity (current ratio) do not affect positive toward profitability (return on assets). In addition the results of the analysis show the sub sectors of the pharmacy in the period 2013-2017 to have the development of profitability (return on assets) through determination of coefficients test 62.9\% of known (working capital turnover, inventory turnover, receivable turnover, current ratio) while the rest of $37.1 \%$ is affected by other variables that are not included in the regression model. While partially (individual) only working capital turnover, receivable turnover Inventory turnover, the effect on profitability (return on assets).
\end{abstract}

Keyword : working capital, liquidity, profitability, pharmaceutical sector

\begin{abstract}
ABSTRAK: Penelitian ini bertujuan untuk menganalisis determinasi dari efisiensi modal kerja dan likuiditas terhadap profitabilitas pada perusahaan farmasi yang terdaftar di Bursa Efek Indonesia. Pendekatan penelitian menggunakan penelitian kuantitatif dengan metode korelasional regresi. Data yang diambil merupakan data sekunder dari BEI. Hasil penelitian menunjukan: pertama modal kerja (working capital turnover) berpengaruh terhadap profitabilitas (return on assets), kedua piutang usaha (receivable turnover) berpengaruh terhadap profitabilitas (return on assets), ketiga persediaan (inventory turnover) berpengaruh terhadap profitabilitas (return on assets), keempat likuiditas (current ratio) tidak berpengaruh positif terhadap profitabilitas (return on assets). Selain itu hasil analisis menunjukan sub sektor farmasi pada periode 2013-2017 memiliki perkembangan profitabilitas (return on assets) melalui uji koefisien determinasi diketahui sebesar 62,9\% (working capital turnover, receivable turnover, inventory turnover, current ratio) sedangkan sisanya sebesar $37,1 \%$ dipengaruhi oleh variabel lain yang tidak termasuk dalam model regresi. Sementara secara parsial (individu) hanya working capital turnover, receivable turnover, Inventory turnover yang berpengaruh terhadap profitabilitas (return on assets).
\end{abstract}

Kata kunci: modal kerja, likuiditas, profitabilitas, sektor farmasi

\section{Pendahuluan \\ a. Latar Belakang}

Perkembangan usaha yang semakin kompetitif, perusahaan dituntut untuk semakin efisien dalam menjalankan aktivitasnya untuk meningkatkan kinerja perusahaan (Kotler, 2005). Agar dapat mempertahankan kelangsungan

usahanya, maka perusahaan dituntut untuk lebih inovatif dan memiliki strategi yang tepat dan cermat agar mampu bertahan dalam perkembangan ekonomi dunia (Keegan, 2015). Perkembangan sektor industri farmasi menarik untuk 
diteliti. Industri ini merupakan salah satu industri yang bertahan di tengah kondisi perekonomian yang semakin berkembang dan sub sektor farmasi di Indonesia juga cukup besar di kawasan Asean. Selain itu banyak perusahaan yang bergerak dibidang farmasi yang berada di Indonesia memiliki permasalahan yang kompleks salah satunya modal kerja. Modal kerja merupakan aktiva lancar dikurangi hutang lancar atau dana yang harus tersedia untuk membiayai kegiatan operasi perusahaan seharihari, misalnya untuk membayar gaji pegawai, membeli bahan baku, membayar hutang dan sebagainya (Sawir, 2012).

Dana yang dialokasikan tersebut diharapkan diterima kembali dari hasil penjualan produk yang dihasilkan dalam waktu yang tidak lama (satu tahun atau kurang dari satu tahun). Dengan demikian, sumber dana tersebut akan terus-menerus berputar setiap periodenya selama hidupnya perusahaan tersedianya modal kerja yang cukup penting bagi perusahaan untuk membiayai kegiatan operasionalnya. Maka pihak perusahaan harus dapat menggunakan modal kerjanya secara efektif dan efisien. Modal kerja yang berlebihan menunjukkan adanya dana yang tidak produktif (Martono \& Harjito, 2012). Hal ini akan menimbulkan kerugian bagi perusahaan yang selanjutnya berakibat pada penurunan tingkat profitabilitas perusahaan. sebaliknya kekurangan modal kerja juga akan menimbulkan kerugian bagi perusahaan karena kesempatan untuk memperoleh keuntungan disia-siakan. Untuk itulah setiap perusahaan dituntut untuk mengelolah modal kerjanya secara efektif dan efisien, agar dapat mengahasilkan laba yang berdampak pada pencapaian profitabilitas yang maksimal bagi perusahaan tersebut.

Bagaimana perusahaan tersebut harus mengefisiensikan modal kerja yang ada untuk mendapatkan keuntungan yang optimal. Manajemen modal kerja dalam suatu perusahaan diperlukan untuk mengetahui jumlah modal kerja optimal yang dibutuhkan perusahaan tersebut (Munawir, 2002). Sehingga adanya analisis atas modal kerja pada perusahaan, analisis tersebut sangat penting dilakukan untuk mengetahui situasi modal kerja pada saat ini. Kemudian hal itu dihubungkan dengan situasi keuangan yang akan dihadapi pada masa yang akan datang.

Menurut Kasmir (2009:250), menyebutkan bahwa modal kerja adalah modal yang digunakan untuk melakukan kegiatan operasi perusahaan. Modal kerja diartikan sebagai investasi yang ditanamkan dalam aktiva lancar atau aktiva jangka pendek, seperti kas, bank, surat-surat berharga, piutang, persediaan, dan aktiva lancar lainnya. Efisiensi modal kerja adalah pemanfaatan modal kerja aktifitas oprasional perusahaan itu sendiri (Agoes, 2017). Penggunaan modal kerja akan dinyatakan optimal jika jumlah modal kerja yang digunakan dalam perusahaan mampu menghasilkan keuntungan yang besar pula bagi perusahaan. Salah satu masalah kebijaksanaan keuangan yang dihadapi suatu perusahaan adalah masalah mengenai efisiensi modal kerja (Fred \& Bringham, 1991).

Penentuan kebijakan modal kerja yang efisien, perusahaan dihadapkan pada masalah adanya pertukaran antara faktor profitabilitas dan likuiditas (Viswanathan, Palanisamy, \& Mahesh, 2016). Jika perusahaan memutuskan menetapkan modal kerja dalam jumlah yang besar, kemungkinan tingkat likuiditas akan terjaga namun kesempatan untuk memperoleh laba yang besar akan menurun yang pada akhirnya berdampak pada menurunnya profitabilitas. Sebaliknya jika perusahaan ingin memaksimalkan profitabilitas, kemungkinan dapat mempengaruhi tingkat likuiditas 
perusahaan. Makin tinggi likuiditas, maka makin baiklah posisi perusahaan di mata kreditur. Oleh karena terdapat kemungkinan yang lebih besar bahwa

perusahaan akan dapat membayar kewajibannya tepat pada waktunya.

Entitas saat ini tidak memiliki dana yang cukup untuk menutupi utang yang sudah jatuh tempo, maka entitas akan mengalami krisis kepercayaan dari berbagai pihak khususnya investor. Ketidak mampuan entitas membayar kewajiban disebabkan oleh berbagai faktor. Pertama, dikarenakan entitas tidak memiliki dana sama sekali. Kedua, entitas memiliki dana namun saat jatuh tempo entitas tidak memiliki dana. Menurut Agus Harjito dan Martono (2012, 53) "Likuiditas adalah mengukur kemampuan perusahaan dalam memenuhi kewajiban-kewajiban finansialnya yang harus segera dipenuhi". Pada dasarnya, jika perusahaan meningkatkan jumlah utang sebagai sumber dananya hal tersebut dapat meningkatkan risiko keuangan. Jika perusahaan tidak dapat mengelola dana yang diperoleh dari utang secara produktif, dapat memberikan pengaruh negatif dan berdampak terhadap menurunnya profitabilitas perusahaan. Sebaliknya jika utang tersebut dapat dikelola dengan baik dan digunakan untuk proyek investasi yang produktif, hal tersebut dapat memberikan pengaruh yang positif dan berdampak terhadap peningkatan profitabilitas perusahaan.

Untuk menjawab pemecahan masalah yang dihadapi oleh perusahaan yang bergerak dibidang sektor farmasi dalam penggunaan dan pengolahan modal kerja yang cukup efisien untuk kegiatan operasional sehari-hari yang dilakukan oleh perusahaan. Jika modal kerja yang diperlukan cukup, tidak berlebihan maupun tidak terlalu rendah, maka tingkat profitabilitas juga akan dapat menjadi lebih baik untuk setiap tahun dan tingkat likuiditas juga akan terus meningkat, jika modal kerja yang digunakan dengan seefisiensi dalam penggunaanya.

Profitabilitas suatu perusahaan menunjukkan perbandingan antara laba dengan aktiva atau modal yang menghasilkan laba tersebut. Dengan kata lain menurut Halim (2007:157), "profitabilitas adalah mengukur sampai seberapa besar efektifitas manajemen dalam mengelolah asset dan equity yang dimiliki perusahaan untuk menghasilkan laba". Menurut Irham Fahmi $(2012,81)$ bahwa Rasio profitabilitas adalah rasio untuk mngukur efektivitas manajemen secara keseluruhan yang ditujukan oleh besar kecilnya tingkat keuntungan yang diperoleh dalam hubungannya dengan penjualan maupun investasi. Semakin baik rasio profitabilitas maka semakin baik menggambarkan kemampuan tingginya perolehan keuntungan perusahaan

Sebagai acuan dalam penelitian ini dikemukakan hasil penelitian yang dilakukan oleh Syahputra (2015) menunjukan bahwa "Pengaruh Efisiensi Modal Kerja dan Likuiditas terhadap Profitabilitas Pada Perusahaan Sektor Farmasi yang terdaftar di Bursa Efek Indonesia (BEI) Pada Periode 2009 Sampai 2014" Hasil penelitian menyimbulkan bahwa variabel modal kerja memiliki pengaruh terhadap rasio profitabilitas. Mengingat besarnya resiko kegiatan perusahaan dapat terpenuhi. Sehingga peningkatan modal kerja, dan pembayaran hutang jangka pendek dapat dibayar, diharapkan dapat meningkatkan laba perusahaan. Maka penulis tertarik untuk melakukan penelitian lebih lanjut pada perusahaan sub sektor farmasi yang terdaftar di 


\section{b. Identifikasi Masalah}

Berdasarkan uraian latar belakang di atas, dapat diidentifikasi permasalahan adalah sebagai berikut: Pengelolaan modal kerja masih belum efektif dan efisian sehingga menarik untuk diteliti.

1) Kondisi laba bersih dan aset bersih yang tidak konsisten dan berfluktuatif pada perusahaan sektor farmasi periode 2013-2017 sehingga menarik untuk dilakukan penelitian kembali.

2) Ketidakpastian dan fluktuasinya harga saham membuat investor perlu berhati-hati menanamkan modalnya di pasar modal.

3) Beberapa hasil penelitian terdahulu masih belum konsisten sehingga menarik untuk dilakukan penilitian kembali.

\section{c. Tujuan Penelitian}

Berdasarkan rumusan masalah di atas adapun tujuan penelitian ini sebagai berikut:

1) Untuk mengetahui perkembangan efisiensi modal kerja pada perusahaan sektor farmasi yang terdaftar di BEI periode 20132017

2) Untuk mengetahui perkembangan likuiditas pada perusahaan sektor farmasi yang terdaftar di BEI periode 2013-2017

3) Untuk mengetahui profitabilitas pada perusahaan sektor farmasi yang terdaftar di BEI periode 2013-2017

4) Untuk mengetahui pengaruh efisiensi modal kerja dan likuiditas terhadap profitabilitas pada perusahaan sektor farmasi yang terdaftar di BEI periode 2013-2017

\section{d. Rumusan Masalah}

Apakah pengaruh efisiensi modal kerja dan likuiditas terhadap profitabilitas pada perusahaan sektor farmasi yang terdaftar di BEI periode 2013-2017?

\section{Kajian Pustaka}

\section{a. Laporan Keuangan}

Laporan keuangan pada umumnya merupakan hasil dari suatu pencatatan transaksi-transaksi yang terjadi pada perusahaan selama periode tertentu. Laporan keuangan yang dibuat dan disusun harus sesuai dengan aturan standar yang berlaku. Setelah seluruh data transaksi dicatat selanjutnya dianalisis sehingga dapat menjadi suatu informasi untuk mengetahui kondisi keuangan dan posisi perusahaan terkini. Laporan keuangan merupakan dasar untuk menentukan langkah apa yang akan diambil oleh perusahaan untuk saat sekarang ini dan kedepannya, dengan melihat berbagai persoalan yang timbul baik kelemahan ataupun kelebihan yang dimiliki.

Menurut Harahap (2013:105) "laporan keuangan menggambarkan kondisi keuangan dan hasil suatu perusahaan pada saat tertentu atau jangka waktu tertentu". Sedangkan Menurut Fahmi (2011:2) "laporan keuangan adalah suatu informasi yang menggambarkan kondisi keuangan suatu perusahaan dan lebih jauh informasi tersebut dapat dijadikan sebagai gambaran kinerja keuangan perusahaan tersebut". Berdasarkan beberapa pengertian di atas, menunjukkan bahwa laporan keuangan adalah suatu laporan yang menggambarkan kondisi keuangan perusahaan dalam periode tertentu sesuai dengan prinsip akuntansi. 
Laporan keuangan yang dibuat oleh perusahaan terdiri dari beberapa jenis. tergantung dari maksud dan tujuan pembuatan laporan keuangan tersebut. Masing-masing laporan keuangan memiliki arti sendiri dalam melihat kondisi keuangan perusahaan, baik secara bagian, maupun secara keseluruhaan. Namun, dalam praktiknya perusahaan dituntut untuk menyusun beberapa jenis laporan keuangan yang sesuai dengan standar yang telah ditentukan, terutama untuk kepentingan diri sendiri maupun untuk kepentingan pihak lain.

\section{b. Modal Kerja}

Permasalahan perusahaan dalam modal kerja merupakan masalah yang tidak akan berakhir, mengingat bahwa masalah modal itu mengandung berbagai jenis aspek. Baik perusahaan besar maupun perusahaan kecil untuk kebutuhan akan modal sangat diperlukan dalam kegiatan oprasinya. Menurut Kasmir ( 2009:250), menyebutkan bahwa modal kerja adalah modal yang digunakan untuk melakukan kegiatan operasi perusahaan. Modal kerja diartikan sebagai investasi yang ditanamkan dalam aktiva lancar atau aktiva jangka pendek, seperti kas, bank, surat-surat berharga, piutang, persediaan, dan aktiva lancar lainnya.

Konsep ini mendasarkan pada fungsi dari dana dalam menghasilkan pendapatan (income). Setiap dana yang digunakan dalam perusahaan dimaksudkan untuk mengahasilkan pendapatan dari usaha pokok perusahaan, tetapi tudak semua dana digunakan untuk menghasilkan pendapatan periode ini (curren income). Dalam konsep fungsional, modal kerja terbagi menjadi tiga yaitu:
1) Working Capital (working capital turnover): Dana yang digunakan selama periode accounting yang dimaksudkan

untuk menghasilkan current income yang sesuai dengan maksud utama didirikan perusahaan tersebut.

2) Potensial Working Capital (receivable turnover) yaitu dana yang tidak sesuai dengan maksud didirikan perusahaan, namun dana tersebut nantinya dapat diambil/digunakan dengan mudah yang selanjutnya dapat diinvestasikan dalam perusahaan.

3) Non Working Capital (inventory turnover) yaitu dana yang tidak menghasilkan current income atau bila menghasilkan current income tidak sesuai dengan maksud utama didirikannya perusahaan terebut.

\section{c. Likuiditas}

Pada saat entitas tidak memiliki dana yang cukup untuk menutupi utang yang sudah jatuh tempo, maka entitas akan mengalami krisis kepercayaan dari berbagai pihak khususnya investor. Ketidak mampuan entitas membayar kewajiban disebabkan oleh berbagai faktor. Pertama, dikarenakan entitas tidak memiliki dana sama sekali. Kedua, entitas memiliki dana namun saat jatuh tempo entitas tidak memiliki dana. Menurut Agus Harjito dan Martono (2012, 53) "Likuiditas adalah mengukur kemampuan perusahaan dalam memenuhi kewajiban-kewajiban finansialnya yang harus segera dipenuhi”.

Sedangkan menurut Irham Fahmi $(2012,57)$ mengatakan bahwa "likuiditas yaitu kemampuan suatu perusahaan memenuhi kewajiban jangka pendeknya secara tepat waktu. Menurut Irham Fahmi likuiditas sering disebut dengan short term liquidity".Dilihat dari pengertian-pengertian di atas maka dapat disimpulkan bahwa rasio 
likuiditas adalah mengukur

kemampuan perusahaan dalam memenuhi kewajiban jangka pendeknya secara tepat waktu. Rasio ini juga sering disebut dengan istilah short term liquidity.

\section{d. Profitabilitas}

Profitabilitas suatu perusahaan menunjukkan perbandingan antara laba dengan aktiva atau modal yang menghasilkan laba tersebut. Dengan kata lain menurut Halim (2007:157), "profitabilitas adalah mengukur sampai seberapa besar efektifitas manajemen dalam mengelolah asset dan equity yang dimiliki perusahaan untuk menghasilkan laba". Menurut Irham Fahmi $(2012,81)$ bahwa Rasio profitabilitas adalah rasio untuk mengukur efektivitas manajemen secara keseluruhan yang ditujukan oleh besar kecilnya tingkat keuntungan yang diperoleh dalam hubungannya dengan penjualan maupun investasi. Semakin baik rasio profitabilitas maka semakin baik menggambarkan kemampuan tingginya perolehan keuntungan perusahaan.

Permasalahan modal kerja dalam perusahaan adalah merupakan kegiatan sehari-hari yang dilakukan oleh perusahaan, khususnya adalah kegiatan yang berhubungan dengan pelaksanaan produksi atau penjualan serta jasa. Aktivitas yang dilakukan secara rutin oleh perusahaan tersebut dimulai dengan sejak perusahaan mengeluarkan biaya atau dana untuk memulai usaha seperti pembelian, persediaan, produksi dan hasil penagihan penjualan.

Semua proses dapat berjalan dengan lancar apabila perusahaan mampu menyediakan dana dalam kas atau modal kerja yang dalam arti aset dan segala sesuatu yang diperlukan perusahaan untuk melaksanakan aktivitas kegiatan rutin. Semua yang diperlukan oleh perusahaan untuk melaksanakan kegiatan rutin tersebut dikenal sebagai pengelolaan modal kerja. Dari sumber diatas maka dapat ditentukan langkah apa dan apa yang harus diambil oleh suatu perusahaan untuk mengatasi permasalahan tersebut.

Perputaran modal kerja dimulai dari saat kas diinvestasikan dalam komponen modal kerja sampai saat kembali menjadi kas. Semakin pendek periode perputaran modal kerja, semakin cepat perputarannya sehimgga pemutaran modal kerja semakin efisien yang pada akhirnya profitabilitas semakin meningkat. Jika perusahaan memutuskan menetapkan modal kerja dalam jumlah yang besar, kemungkinan tingkat likuiditas akan terjaga namun kesempatan untuk memperoleh laba yang besar akan menurun yang pada akhirnya berdampak pada menurunya profitabilitas. Sebaliknya jika perusahaan ingin mengoptimalkan profitabilitas, kemungkinan dapat mempengaruhi tingkat likuiditas perusahaan. Setiap perusahaan dalam menjalankan kegiatan usahanya selalu berusaha untuk mendapatkan laba yang maksimal. Perusahaan akan selalu menggunakan modal kerja yang dimiliki secara optimal agar mendapatkan laba. Laba atau profit digunakan perusahaan guna dapat melangsungkan usaha perusahaan secara terus-menerus.

\section{Metode Penelitian}

Penelitian ini menganalisis perusahaan sub sector farmasi yang terdaftar di Bursa Efek Indonesia, perusahaan - perusahaan tersebut diantaranya PT Merck Tbk, PT Kalbe Farma Tbk, PT Tempo Scan Pasifik Tbk, PT Kimia Farma (Persero) Tbk, PT Darya Varia Laboratoria Tbk dan PT Pyridam Farma Tbk. Variabel independen (variabel bebas) dalam penelitian ini variabel independen yaitu efisiensi modal kerja dan 
likuiditas sedangkan variabel dependennya adalah profitabilitas. Jenis atau bentuk penelitian yang digunakan adalah penelitian kuantitatif yaitu sebuah penelitian yang datanya berupa angka (Cohen, Manion, \& Morrison, 2007). Data yang digunakan pada penelitian ini menggunakan data skunder berupa ratio-ratio dari efisiensi modal kerja, ratio dari likuiditas dan ratio profitabilitas dari Annual Report dan laporan keuangan perusahaan farmasi yang terdaftar di Bursa Efek Indonesia (BEI) pada periode 20132017. Analisis statistic yang digunakan menggunakan analisis statistik inferensial (Sugiarto, 2006). Pengujian dilakukan dengan analisis regresi linier berganda yaitu sebuah pengujian untuk melihat tingkat keeratan pengaruh antar variable (Efferin \& Sujoko et al, 2004). Analisis regresi linier berganda digunakan peneliti dengan maksud untuk mengetahui besarnya pengaruh Modal Kerja dan Likuiditas terhadap Profitabilitas. Persamaan yang menyatakan bentuk hubungan antara variabel independen $(\mathrm{X})$ dan bariabel dependen (Y) disebut dengan persamaan regresi.

Berdasarkan pada uraian kerangka pemikiran diatas, maka penulis mencoba memberikan hipotesis penelitian yang disusun sebagai berikut:

H1 : Efisiensi Modal kerja (working capital turnover) berpengaruh terhadap profitabilitas (return on assets).

$\mathrm{H} 2$ : Efisiensi receivable turnover berpengaruh terhadap profitabilitas (return on assets).

H3 : Efisiensi inventory turnover berpengaruh terhadap profitabilitas (return on assets).

H4 : Likuiditas (current ratio) berpengaruh terhadap profitabilitas (return on assets).

H5 : Efisiensi working capital turnover, receivable turnover, inventory turnover dan Likuiditas (current ratio) secara bersama-sama berpengaruh terhadap Profitabilitas (return on assets)

\section{Hasil Dan Pembahasan}

Berdasarkan data penelitian yang berasal dari laporan keuangan perusahaan yang terdaftar di Bursa Efek Indonesia, khususnya pada perusahan yang tergabung dalam sub sektor farmasi. Penelitian ini akan menganalisa tentang pengaruh efisiensi modal kerja dan likuiditas terhadap profitabilitas. Objek penelitian ini adalah efisiensi modal kerja yang di ukur dengan menggunakan 2 variabel independen yaitu modal kerja dan likuiditas dan variabel dependen menggunakan profitabilitas. Adapun perusahaanperusahaan yang bergerak di sub sektor farmasi yang terdaftar di BEI periode 2013 sampai dengan 2017.

Unit analisis yang digunakan dalam penelitian ini berupa organization yaitu sumber data yang unit analisis yang merupakan respon dari divisi organization yaitu Bursa Efek Indonesia. Lokasi penelitian yang dilakukan penulis yaitu pada perusahaan sub sektor industry farmasi di Bursa Efek Indonesia (BEI). Pengumpulan data dan informasi dengan menggunakan data sekunder yaitu sumber yang tidak langsung memberikan data kepada pengumpul data, jadi penulisan mendapatkan data dan informasi melalui Bursa Efek Indonesia (BEI).

Data yang dijadikan sampel dalam penulisan ini berjumlah 6 perusahaan. Sedangkan metode pemilihan sampel yang digunakan adalah purposive sampling, yaitu pengambilan sampel secara sengaja sesuai dengan persyaratan sampel 
Tabel 1. Daftar Sampel Perusahaan Sub Sektor Farmasi

\begin{tabular}{cccc}
\hline No & Kode Saham & Nama Perusahaan & Tanggal IPO \\
\hline 1 & MERK & Merck Indonesia Tbk & 23 Juli 1981 \\
2 & KLBF & Kalbe Farma Tbk & 30 Juli 1991 \\
3 & TSPC & Tempo Scan Pasifik Tbk & 17 Januari 1994 \\
4 & KAEF & Kimia Farma (Persero) Tbk & 14 Juni 2001 \\
5 & DVLA & Darya Varia Laboratoria Tbk & 12 Oktober 1994 \\
6 & PYFA & Pyridam Farma Tbk & 25 April 2001 \\
\hline
\end{tabular}

Sebelum dilakukan uji regresi dilakuakan asumsi klasik diantaranya adalah uji normalitas dan uji multikolonieritas.

Tabel 2. Uji Normalitas dengan Kolmogorov-Smirnov Test

Data

$\mathrm{N}$

Normal Parameters ${ }^{\mathrm{a}, \mathrm{b}}$

Most Extreme Differences

Test Statistic

Asymp. Sig. (2-tailed)

a. Test distribution is Normal.

b. Calculated from data.
Residual

30

Mean

, 0000000

Std.

3,63123803

Deviation

Absolute

, 119

Positive

Negative

,119

, $200^{\mathrm{c}, \mathrm{d}}$

Dari hasil pengolahan data tersebut, besarnya nilai Kolmogorof Smirnov adalah 0,119 dengan signifikansi sebesar 0,200 Oleh karena itu, dapat disimpulkan bahwa perhitungan Kolmogorof Smirnov (K-S) menunjukan data dalam model regresi berdistribusi secara normal. Dimana data memiliki nilai asymptotic lebih dari 0,05 $(0,200>0,05)$.

Gambar 1. Grafik Normal P-P Plot ROA

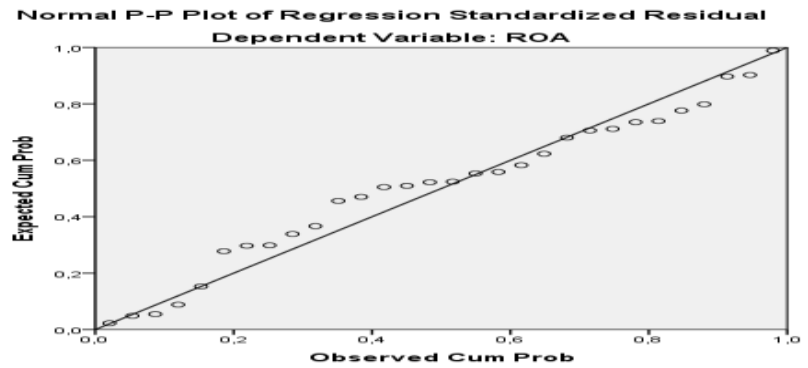


Berdasarkan gambar diatas menunjukan data menyebar disekitar garis diagonal dan mengikuti arah diagonal, maka model regresi memenuhi dasumsi normalitas. Sehingga data dapat dilakukan uji lanjutan.

Tabel 3 Hasil Uji Multikolineraritas Coefficient

\begin{tabular}{lrrrrrrr}
\hline & \multicolumn{2}{c}{ Unstandardized } & \multicolumn{3}{c}{ Standardized } & \multicolumn{3}{c}{ Collinearity } \\
\cline { 2 - 8 } Model & \multicolumn{1}{c}{ B } & Std. Error & Beta & $\mathrm{t}$ & $\mathrm{S} i g$ & Toleran & VIF \\
\hline (Constant) & 13,733 & 10,336 & & 1,329 & 0,196 & & \\
WCT & $-2,629$ & 1,042 & $-0,619$ & $-2,524$ & 0,018 & 0,21 & 4,71 \\
RT & 1,876 & 0,441 & 0,647 & 4,249 & 0 & 0,55 & 1,82 \\
IT & $-3,221$ & 1,254 & $-0,485$ & $-2,568$ & 0,017 & 0,36 & 2,78 \\
CR & 1,07 & 1,68 & 0,161 & 0,637 & 0,53 & 0,2 & 5,01
\end{tabular}

Berdasarkan tabet di atas, diketahui bahwa nilai Tolerance ke empat variabel lebih dari 0,10 dan nilai VIF kurang dari 10. Maka dapat disimpulkan bahwa tidak terjadi masalah multikolinearitas antar variabel independen pada model regresi.

Uji hipotesisi menggunakan alat analisis determinasi $\left(\mathrm{R}^{2}\right)$ bertujuan untuk mengukur kemampuan model dalam menerangkan variabel dependen. Nilai koefisien determinasi antara nol sampai dengan satu. Nilai determinasi $\left(\mathrm{R}^{2}\right)$ yang kecil berarti kemampuan variabel-variabel independen dalam menjelaskan variasi variabel dependen amat terbatas.

Tabel 4. Hasil Uji Determinasi

\begin{tabular}{c|r|r|r|r}
\hline $\mathrm{R}$ & R Square & \multicolumn{1}{|c}{$\begin{array}{c}\text { Adjusted R } \\
\text { Square }\end{array}$} & $\begin{array}{c}\text { Std. Error of } \\
\text { the Estimate }\end{array}$ & $\begin{array}{l}\text { Durbin- } \\
\text { Watson }\end{array}$ \\
\hline $0,825^{\mathrm{a}}$ & 0,68 & 0,629 & 3,91096 & 0,893 \\
\hline
\end{tabular}

Berdasarkan pada tabel di atas diperoleh angka $\mathrm{R}^{2}$ ( $\mathrm{R}$ Square) sebesar 0,629 atau $(62,9 \%)$. Hal ini menunjukkan bahwa presentase sumbangan pengaruh variabel independen (working capital turnover, receivable turnover, inventory turnover, current ratio) terhadap variabel dependen (return on assets) sebesar 62,9\%. Sedangkan sisanya sebesar $37,1 \%$ dipengaruhi atau dijelaskan oleh variabel lain yang tidak dimasukkan dalam model penelitian ini. 
Tabel 5. HasilPengujian $F$

\begin{tabular}{|c|c|c|c|c|c|}
\hline & $\begin{array}{l}\text { Sum of } \\
\text { Squares }\end{array}$ & $\overline{\mathrm{Df}}$ & $\begin{array}{l}\text { Mean } \\
\text { Square }\end{array}$ & $\mathrm{F}$ & Sig. \\
\hline Regression & 813,842 & 4 & 203,461 & 13,302 &, $001^{\mathrm{b}}$ \\
\hline Residual & 382,391 & 25 & 15,296 & & \\
\hline Total & 1196,233 & 14 & & & \\
\hline
\end{tabular}

Berdasarkan tabel diketahui signifikansi $0,001^{\mathrm{b}}$ dan nilai $\mathrm{F}$ test sebesar 13,302. Hal ini tidak sesuai dengan hasil pengujian statistik yang membandingkan antara $\mathrm{F}$ hitung dengan $F$ tabel, nilai $F$ tabel $(0,05 ; 4 ; 25)$ adalah 2,69 maka hasilnya, $\mathrm{F}$ hitung $>\mathrm{F}$ tabel $(13,302$
> 2,69) sehingga dapat disimpulkan bahwa variabel independen receivable turnover, inventory turnover, working capital turnover, current ratio secara simultan mempengaruhi variabel dependen ROA.

Tabel 6. Hasil Uji t (Parsial)

\begin{tabular}{crrrr|r}
\hline Model & \multicolumn{2}{c}{ Unstandardized } & $\begin{array}{c}\text { Standardized } \\
\text { Coefficients }\end{array}$ & T & Sig. \\
& B & $\begin{array}{c}\text { Std. } \\
\text { Error }\end{array}$ & Beta & & \\
& & & & \\
\hline (Constant) & 13,733 & 10,336 & & 1,329 & 0,196 \\
WCT & $-2,629$ & 1,042 & $-0,619$ & - & 0,018 \\
& & & & 2,524 & \\
RT & 1,876 & 0,441 & 0,647 & 4,249 & 0 \\
IT & $-3,221$ & 1,254 & $-0,485$ & - & 0,017 \\
& & & & 2,568 & \\
\hline CR & 1,07 & 1,68 & 0,161 & 0,637 & 0,53 \\
\hline
\end{tabular}

Nilai signifikansi working capital turnover sebesar 0,018 kurang dari 0,05 (sig. $\mathrm{t}<0,05$ ) telah sesuai dengan hasil pengujian statistik yang membandingkan antara $t$ hitung dengan $t$ tabel. Hal ini ditunjukkan dengan $\mathrm{t}$ hitung $>\mathrm{t}$ tabel $(2,524>1,708)$. Nilai signifikansi receivable turnover sebesar 0,000 kurang dari 0,05 (sig. $\mathrm{t}<0,05$ ). Hal ini sesuai dengan hasil pengujian statistik yang membandingkan antara $\mathrm{t}$ hitung dengan $\mathrm{t}$ tabel, nilai $\mathrm{t}$ tabel $(0,05 ; 25)$ adalah 1,70814 maka hasilnya, $\mathrm{t}$ hitung > $\mathrm{t}$ tabel $(4,249<$ 1,708).Nilai signifikansi inventory turnover sebesar 0,017 lebih kecil dari 0,05 (sig. $t>0,05$ ) telah sesuai dengan hasil pengujian statistik yang membandingkan antara $t$ hitung dengan $t$ tabel. Hal ini ditunjukkan dengan $\mathrm{t}$ hitung $<\mathrm{t}$ tabel $(2,568<$ 1,708).Nilai signifikansi current ratio sebesar 0,530 lebih dari 0,05 
(sig. $\mathrm{t}>0,05)$ sesuai dengan hasil pengujian statistik yang membandingkan antara $t$ hitung dengan $t$ tabel. Hal ini ditunjukkan turnover, receivable turnover memiliki pengaruh terhadap return on assets sedangkan Analisis regresi linier berganda menggunakan dua atau lebih variabel independen yang digunakan. Analisis regresi berganda adalah analisis yang digunakan untuk mengukur besar pengaruh dua atau lebih variabel independen terhadap dengan $\mathrm{t}$ hitung $<\mathrm{t}$ tabel $(0,637$ $<1,812)$.Dua variabel independen tersebut yang dimasukkan ke dalam model regresi ini working capital inventory turnover, current ratio tidak memiliki pengaruh

satu variabel dependen. Berikut ini adalah persamaan regresi linier berganda.

$$
Y=a+b^{1} \cdot X^{1}+b^{2} \cdot X^{2}+b^{3} \cdot X^{3}+b^{4} \cdot X^{4}
$$

Tabel 7. Hasil Persamaan Regresi Linear Berganda

\begin{tabular}{lrrrrr}
\hline \multicolumn{7}{c}{$\begin{array}{c}\text { Unstandardized } \\
\text { Coefficients }\end{array}$} & $\begin{array}{c}\text { Standardized } \\
\text { Coefficients }\end{array}$ & $\mathrm{t}$ & Sig. \\
& & & & & \\
\hline (Constant) & B & $\begin{array}{c}\text { Std. } \\
\text { Error }\end{array}$ & Beta & & \\
\hline WTC & $-2,6$ & 1,04 & $-0,619$ & - & 0,018 \\
RT & & & & 2,524 & \\
ITO & 1,88 & 0,44 & 0,647 & 4,249 & 0 \\
& $-3,2$ & 1,25 & $-0,485$ & - & 0,017 \\
CR & & & & 2,568 & \\
& 1,07 & 1,68 & 0,161 & 0,637 & 0,53 \\
\hline
\end{tabular}

Berdasarkan tabel diatas diperoleh persamaan regresi sebagai berikut: ROA $=13,733+-$ $2,629+1,876+-3,211+1,070$

Dari hasil persamaan regresi berganda tersebut dijelaskan bahwa:

1) $\quad \beta 0=$ konstanta sebesar 13,733 artinya apabila semua variabel independen (WCTO, RTO, ITO, dan CR) dianggap konstan (bernilai 0), maka return on assets akan mengalami penurunan sebesar 13,733.

2) Working Capital Turnover (WCTO) sebesar 2,629 artinya apabila working capital turnover perusahaan naik sebesar 1 satuan sedangkan variabel lainnya dianggap konstan maka return on assets akan mengalami kenaikan sebesar 2,629 satuan.

3) Receivable Turnover (RTO) sebesar 1,876 artinya apabila receivable turnover perusahaan naik sebesar 1 satuan sedangkan variabel lainnya dianggap konstan maka return on assets akan mengalami penurunan sebesar 1,876 satuan.

4) Inventory Turnover (ITO) sebesar 3,211 artinya apabila inventory turnover perusahaan naik sebesar 1 satuan sedangkan 
variabel lainnya dianggap

konstan maka return on assets

akan mengalami penurunan

sebesar 3,211 satuan.

5) Current Ratio (CR) sebesar

1,070 artinya apabila current ratio perusahaan turun sebesar 1 satuan sedangkan variabel lainnya dianggap konstan maka return on assets akan mengalami penurunan sebesar 1,070 satuan.

Tabel 8 Hasil Pengujian Hipotesis Penelitian

\begin{tabular}{|c|c|c|}
\hline Kode & Kriteria & Hasil \\
\hline $\mathrm{H}_{1}$ & $\begin{array}{l}\text { Efisiensi Modal kerja (working capital turnover) } \\
\text { berpengaruh terhadap profitabilitas (return on assets). }\end{array}$ & Diterima \\
\hline $\mathrm{H}_{2}$ & $\begin{array}{l}\text { Efisiensi Modal kerja (receivable turnover) berpengaruh } \\
\text { terhadap profitabilitas (return on assets). }\end{array}$ & Diterima \\
\hline $\mathrm{H}_{3}$ & $\begin{array}{l}\text { Efisiensi Modal kerja (inventory turnover) berpengaruh } \\
\text { terhadap profitabilitas (return on assets). }\end{array}$ & Diterima \\
\hline $\mathrm{H}_{4}$ & $\begin{array}{l}\text { Likuiditas (current ratio) } \\
\text { profitabilitas (return on assets). }\end{array}$ & Ditolak \\
\hline $\mathrm{H}_{5}$ & $\begin{array}{l}\text { Efisiensi Modal Kerja (working capital turnover, } \\
\text { receivable turnover, inventory turnover) dan Likuiditas } \\
\text { (current ratio) secara bersama-sama berpengaruh terhadap } \\
\text { Profitabilitas (return on assets) }\end{array}$ & Diterima \\
\hline
\end{tabular}

Berdasarkan tabel diatas, berikut ini dijelaskan mengenai hasil dari hipotesis penelitian sehingga menghasilkan hipotesis yang diterima atau ditolak.

1) $\mathrm{H}_{1}$ : Diterima

Nilai signifikansi working capital turnover sebesar 0,018 lebih kecil dari 0,05 (sig. $t>0,05$ ) telah sesuai dengan hasil pengujian statistik yang membandingkan antara $\mathrm{t}$ hitung dengan $t$ tabel. Hal ini ditunjukkan dengan $\mathrm{t}$ hitung $>\mathrm{t}$ tabel $(2,524<$ 1,708). Sehingga kesimpulanya adalah modal kerja (working capital turnover) berpengaruh tehadap profitabilitas (return on assets) dan hipotesis diterima.

2) $\mathrm{H}_{2}$ : Diterima

Nilai signifikansi receivable turnover sebesar 0,000 lebih kecil dari 0,05 (sig. $\mathrm{t}>0,05$ ). Hal ini sesuai dengan hasil pengujian statistik yang membandingkan antara $\mathrm{t}$ hitung dengan $t$ tabel, nilai $t$ tabel $(0,05 ; 25)$ adalah 1,708 maka hasilnya, $t$ hitung $>\mathrm{t}$ tabel $(4,249>1,708)$. Dapat disimpulkan bahwa modal kerja (receivable turnover) berpengaruh terhadap profitabilitas (return on assets) dan hipotesis diterima.

\section{3) $\mathrm{H}_{3}$ : Diterima}

Nilai signifikansi inventory turnover sebesar 0,017 lebih kecil dari 0,05 (sig. $t>0,05$ ) telah sesuai dengan hasil pengujian statistik yang membandingkan antara $t$ hitung dengan $t$ tabel. Hal ini ditunjukkan dengan $\mathrm{t}$ hitung $>\mathrm{t}$ tabel $(2,568>$ 1,708). Jadi disimpulkan bahwa modal kerja (inventory turnover) berpengaruh terhadap profitabilitas (return on assets) dan hipotesis diterima.

4) $\mathrm{H}_{4}$ : Ditolak

Nilai signifikansi current ratio sebesar 0,530 lebih dari 0,05 (sig. t > $0,05)$ telah sesuai dengan hasil pengujian statistik yang membandingkan antara $t$ hitung dengan $t$ tabel. Hal ini ditunjukkan dengan $\mathrm{t}$ hitung $>\mathrm{t}$ tabel $(0,637>$ 1,708). Sehingga kesimpulanya adalah likuiditas (current ratio) tidakberpengaruh terhadap 
profitabilitas (return on assets.) dan hipotesis tidak diterima.

5) $\mathrm{H}_{5}:$ Diterima

Berdasarkan tabel 4.12 diketahui signifikansi $0,001^{\mathrm{b}}$ dan nilai $\mathrm{F}$ test sebesar 13,302 . Hal ini tidak sesuai dengan hasil pengujian statistik yang membandingkan antara $\mathrm{F}$ hitung dengan $\mathrm{F}$ tabel, nilai $\mathrm{F}$ tabel $(0,05 ; 4 ; 25)$ adalah 2,69 maka hasilnya, $\mathrm{F}$ hitung $>\mathrm{F}$ tabel $(13,302>3,48)$ sehingga dapat disimpulkan bahwa variabel independen receivable turnover, inventory turnover, working capital turnover, current ratio secara simultan mempengaruhi variabel dependen ROA.

Berdasarkan hasil penelitian ini, maka penelitian ini menginterpretasikan Working Capital Turnover berpengaruh terhadap return on assets.Return On Assets mengukur kemampuan perusahaan menghasilkan laba bersih berdasarkan tingkat aset tertentu. Working Capital Turnover bertujuan untuk mengukur seberapa banyak modal kerja berpitar dalam suatu periode. Jadi, apabila working capital turnover mengalami kenaikan maka tidak akan berpengaruh pada return on assets.

Perusahaan-perusahaan farmasi yang dipilih harus meningkatkan rasio lancar yang di atas. Untuk meningkatkan rasio lancar Perusahaan harus menambah modal atau mengurangi kewajiban mereka saat ini. Rasio cepat cukup dikelola oleh semua perusahaan dalam skala besar dan menengah skala. Mereka harus mempertahankan yang sama di tahun yang akan datang. Perusahaanperusahaan yang dipilih harus meningkatkan mereka meminjam dengan bunga minimum. Menggunakan perdagangan pada ekuitas teknik untuk meningkatkan kekayaan pemegang saham ekuitas. Modal kerja adalah dasar untuk operasi sehari-hari bisnis. Analisis rasio menyediakan panduan dan petunjuk terutama di tempat trend terhadap kinerja yang lebih baik atau buruk dan mengetahui signifikan penyimpangan dari standar apapun rata-rata atau relatif berlaku. Analisis dari posisi modal kerja telah dibagi menjadi dua bagian utama.

\section{Simpulan Dan Saran}

Berdasarkan hasil penelitian ini perusahaan sub sektor farmasi pada periode 2013-2017 memiliki perkembangan modal kerja seperti.

1. Rata-rata perkembangan nilai signifikan working capital turnover perusahaan telah sesuai dengan hasil pengujian statistik yang membandingkan antara $t$ hitung dengan $\mathrm{t}$ tabel. Sehingga kesimpulanya adalah modal kerja (working capital turnover) berpengaruh terhadap profitabilitas (return on assets) dan hipotesis diterima. (Working Capital Trunover) bertujuan untk mengukur seberapa banyak modal kerja berputar dalam satu periode. Jadi, apa bila (Working Capital Trunover) mengalami kenaikan maka akan akan berpengaruh pada (return on assets).

2. Rata-rata perkembangan nilai signifikan (receivable turnover) perusahaan. Hal ini sesuai dengan hasil pengujian statistik yang membandingkan antara $t$ hitung dengan $t$ tabel. Sehingga dapat disimpulkan bahwa modal kerja (receivable turnover) berpengaruh terhadap profitabilitas (return on assets) dan hipotesis diterima. (Receivable Turnover) bertujuan untuk mengukur berapa kali dana yang tertanam dalam piutang berputar dalam satu periode. Jadi apabila (receivable turnover) mengalami kenaikan maka (return on 
assets) juga mengalami kenaikan dan sebaliknya.

3. Rata-rata perkembangan nilai signifikan (inventory turnover) perusahaan. Hal ini telah sesuai dengan hasil pengujian statistik yang membandingkan antara $t$ hitung dengan $\mathrm{t}$ tabel. Jadi disimpulkan bahwa modal kerja (inventory turnover) berpengaruh terhadap profitabilitas (return on assets) dan hipotesis diterima. (Inventory Turnover) bertujuan untuk mengukur berapa kali dana yang ditanam dalam persediaan berputar dalam suatu periode. Jadi apabila (inventory turnover) mengalami penurunan maka akan sangat berpengaruh pada (return on assets).

4. Berdasarkan hasil penelitian ini perusahaan sub sektor farmasi pada periode 2013-2017 memiliki perkembangan likuiditas seperti ratarata perkembangan nilai signifikan (current ratio) perusahaan. Hal ini telah sesuai dengan hasil pengujian statistik yang membandingkan antara $\mathrm{t}$ hitung dengan $\mathrm{t}$ tabel. Sehingga kesimpulannya adalah likuiditas (current ratio) tidakberpengaruh positif terhadap profitabilitas (return on assets) dan hipotesis tidak terima. (Current Ratio) bertujuan untuk mengukur kemampuan perusahaan dalam memenuhi kewajibankewajiban finansialnya yang harus segera dibayar tepat waktu. Jadi apabila (current ratio) mengalami kenaikan maka akan berpengaruh pada (return on assets).

5. Berdasarkan hasil penelitian ini perusahaan sub sektor farmasi pada periode 2013-2017 memiliki perkembangan profitabilitas (return on assets) melalui uji koefisien determinasi diketahui sebesar $62,9 \%$ (working capital turnover, receivable turnover, inventory turnover, current ratio) sedangkan sisanya sebesar $37,1 \%$ dipengaruhi oleh variabel lain yang tidak termasuk dalam model regresi. (Return On Assets) Bertujuan mengukur kemampuan suatu perusahaan untuk menghasilkan laba dalam suatu periode tertentu dengan asset yang dimiliki oleh perusahaan tersebut.

Berdasarkan hasil penelitian ini perusahaan sub sektor farmasi pada periode 2013-2017. Hasil penelitian dengan pengujian statistik menunjukkan secara simultan (bersama-sama) bahwa modal kerja dan likuiditas berpengaruh terhadap profitabilitas. Sementara secara parsial (individu) hanya working capital turnover, receivable turnover, Inventory turnover yang berpengaruh terhadap profitabilitas (return on assets). Hal ini menunjukkan bahwa apabila working capital turnover, receivable turnover, Inventory turnover dan mengalami kenaikan maka return on assets juga mengalami hal yang sama.

\section{Daftar Pustaka}

Agoes, S. (2017). Petunjuk Praktis Pemeriksaan Akuntan oleh Akuntan Publik Buku 1. Jakarta: Salemba Empat.

Bursa Efek Indonesia. (2017). Laporan Keuangan Tahunan 2017. Jakarta. Retrieved from http://www.idx.co.id

Cohen, L., Manion, L., \& Morrison, K. (2007). Research Methods in Education, sixth edition. New York: Routledge.

Efferin, \& Sujoko et al. (2004). Metode Penelitian untuk Akuntansi. Malang: Bayumedia Publishing.

Fred, W. J., \& Bringham. (1991). Manajemen Keuangan Jilid II. Edisi Ketujuh. Jakarta: Penerbit Erlangga.

Halim, A. (2007). Akuntansi Sektor Publik: Akuntansi Keuangan Daerah. Yogyakarta: UPP STIM. 
Harahap, S. (2011). Analisis Krisis atas Laporan Keuangan. Jakarta: Rajawali.

Harahap, S. (2011). Teori Akuntansi Edisi Revisi. Jakarta: Rajawali Pers.

Harjito, A., \& Martono. (2012). Manajemen keuangan Yogyakarta: Ekonosia.

Irham, F. (2012). Analisis Laporan Keuangan. Bandung: Alfabeta.

Kasmir. (2012). Analisis laporan keuangan . Jakarta: Rajagrafindo Persada.

Keegan, W. (2015). Global Marketing Manajement 8 th Edition. New Jersey: Prentice. New Jersey: Prentice Hall.

Kotler, P. (2005). Manajemen Pemasaran. Jakarta: PT Indeks. Kelompok Gramedia.

Martono, \& Harjito, A. (2012). Manajemen keuangan Yogyakarta: Ekonosia.

Munawir, S. (2002). Analisis Laporan Keuangan. Edisi Keempat. Yogyakarta: Penerbit Liberty.
Octavianty, E., \& Syahputra, D. (2015). Pengaruh Efisiensi Modal Kerja Dan Likuiditas Terhadap Profitabilitas Pada Perusahaan Sub Sektor Farmasi Yang Terdaftar Di Bursa Efek Indonesia (BEI). Jurnal Ilmiah Akuntansi Fakultas Ekonomi, 1(2), 41-50.

Sawir, A. (2012). Analisis kinerja keuangan dan perancanaan keuangan perusahaan. Jakarta: Gramedia Pustaka Utama .

Sugiarto, D. S. (2006). Metode Statistik Bisnis. Jakarta: PT Gramedia Pustaka.

Viswanathan, M., Palanisamy, A., \& Mahesh, R. (2016). A comparitive study on working capital management of selected pharmaceutical companies in India. IRA-International Journal of Management \& Social Sciences, 3(3), 499-511. 